\title{
Tracing Roman lead sources using lead isotope analyses in conjunction with archaeological and epigraphic evidence- a case study from Augustan/Tiberian Germania
}

\author{
Michael Bode • Andreas Hauptmann • Klaus Mezger
}

Received: 4 June 2009 / Accepted: 2 September 2009 /Published online: 2 October 2009

(C) Springer-Verlag 2009

\begin{abstract}
In antiquity, lead played an important role both for the military and general public. Building construction, in particular, consumed large amounts of this metal. Nevertheless, the supply sources for lead during the Roman Imperial period have not been satisfactorily accounted for. The following paper aims to clarify the provenance of lead artefacts from Roman military fortresses and camps located to the east of the river Rhine in Germany as well as Roman lead ingots whose inscriptions point to a production in Germania. The time frame of both artefact types is Augustan-Tiberian. In view of the archaeological and historical findings pertaining to this period in Roman history, it could be shown, using lead isotope data, that not only were the military bases on the Rhine supplied apparently with lead from the nonferrous ore deposits in the northern Rhine Massif but also other parts of the empire including, most probably, ancient Rome itself.
\end{abstract}

Keywords Roman · Lead · Ingots · Artefacts · Isotope · Inscription · Provenance

M. Bode $(\bowtie) \cdot$ A. Hauptmann

Deutsches Bergbau-Museum Bochum,

Research Laboratory for Archaeology and Materials Science,

Hernerstraße 45,

44787 Bochum, Germany

e-mail: michael.bode@bergbaumuseum.de

\section{A. Hauptmann}

Faculty of Historical Science, Ruhr-Universität Bochum,

Universitätsstraße 150,

44801 Bochum, Germany

\section{K. Mezger}

Institute of Mineralogy and Central Laboratory of Geochronology (ZLG), Westfälische Wilhelms-Universität Münster,

Corrensstraße 24,

48149 Münster, Germany

\section{Introduction}

In contrast with the amount of attention paid by historians and in ancient literary sources to precious metals, lead has always stood in the shadow, even of copper, which was also used for coinage. Lead does not possess such attributes as a pleasing colour, high sheen, or exceptional rigidity. Furthermore, lead develops an unsightly oxidation layer after a short period of time and, because of its weight, is not useful for the production of short-range weapons. Even so, the exploitation of lead ores continually increased during the Copper, Bronze and Iron ages. During this time, knowledge spread that the sought-after precious metal silver could be extracted from molten lead. There was an observable increase in consumption of silver-bearing ore especially after the introduction of silver coins during classical antiquity (Wagner and Pernicka 1988).

The economical importance of lead changed during the period of history dominated by the Roman world. The increase in production of lead can be mostly traced back to the immense demand for the metal in urban construction, a use of lead that had begun in the Greek Archaic/Classical times (Conophagos 1980; Hopper 1968). Due to its very low melting point, lead was used in large quantities to coat the iron brackets and anchors that held the stone blocks together. It has been estimated, for example, that the construction of the famous Porta Nigra in Trier (D) needed seven tonnes of lead for this purpose (Schwinden 2001). Additionally, buildings were covered with lead sheet, and statues were set in their sockets with lead. The metal was used, among others, for the production of pipes, containers, sarcophagi, fillings, product labels, brine evaporation tanks and slingshots. Ships also used lead for anchors, net sinkers, for the manufacture of parts for the pumps or 
simply as ballast in the hold (Rosen and Galili 2007). The average yearly consumption of the metal during Roman times has been estimated to be between 80,000 and 100,000 tons (Nriagu 1996).

This study presents new results about Roman lead production in Germania and the transport of lead in the early Roman Imperial period (Augustan-Tiberian), which has been obtained through close cooperation between natural science and archaeology (Rothenhöfer 2003; Hanel and Rothenhöfer 2005; Durali-Müller 2005; Körlin 2006; Bode 2008).

\section{Some remarks on the historical and archaeological background}

Two groups of artefacts are presented in this paper. The first one is a collection of lead finds from Augustan Roman military camps in Germania east of the river Rhine, altogether c. 150 objects [lead isotope analyses (LIA) s. Durali-Müller 2005; Bode 2008 (cf. Table 1)]. The second group comprises 145 Roman lead ingots whose inscriptions and accompanying finds point to the Augustan-Tiberian emperorship (Rothenhöfer 2005; Hanel and Rothenhöfer 2005). In particular, the ingots are marked with the addition "PLVMB(VM) GER(M (ANICVM)" (v.i.), thus giving rise to the assumption that they were produced in Roman Germania. In total, 11 ingots have been analysed for lead isotope composition (LIA s. Trincherini et al. 2001; Bode 2008 (cf. Table 1, LIA of the Roman lead ingot from Tongeren (B) (v.i.) will be published soon).

The provenance study of the Roman lead artefacts (Group 1) is concentrated in a narrow historical time frame because the eastern part of Germania was under Roman control for no more than two decades ( $9 / 8$ BC to 9 AD). All of the lead artefacts came from military camps, one civil colony and one battlefield located in that region. However, this temporal restriction is an advantage since, after the retreat of the Roman legions, lead scrap was most probably not recycled. Such recycling of "old" lead can be particularly problematic for provenance studies of late Roman metal objects.

It is not possible to exactly date the production of the "PLVMBVM GERMANICVM" ingots (Group 2) to a specific year or decade. More of interest here was to find mines in Germania that could have supplied lead ingots for the Roman world. They should have the same sources that supplied the Roman troops stationed in Germania with lead and thus, hopefully, aside from a new contribution to supraregional transport within the Roman Empire, the provenance of the Roman lead artefacts (Group 1) can be verified.
Military campaigns of Augustus and Tiberius in Germania

It is not completely clear what prompted Augustus to rally troops from Gaul to the Rhine during the second decade BC and send them into enemy territory. It has been argued that, in the long run, the Romans were aiming to create a new province out of Germania (e.g. V. Schnurbein V. 2003; Eck 2004). The headquarters Vetera castra [Xanten (D)] and Mogontiacum [Mainz (D)] were situated at the confluences of the Rhine with the Lippe and Main rivers. Additional troops were stationed in Bonn (D), Neuss (D) and Nijmegen (NL).

During the first campaigns from 12 to $9 / 8 \mathrm{BC}$, which were successful in the end, military camps were built east of the Rhine on Germanic territory. A political tool used in order to stabilise the situation was officially to ally cooperative tribal leaders and award them Roman citizenship. As under Caesar, Germanic tribes not only joined the Roman army but also started a lively trade. But not all the Germanic tribes lived in harmony with the Romans. Rebellions followed from $1 \mathrm{AD}$ to $5 \mathrm{AD}$ that could only be put down at great cost (Wiegels 2007), and in 9 AD, Germanic tribes overpowered three legions in the Clades Variana, which caused the retreat of the Romans from almost all of Germania east of the Rhine and a break in the political alliance with Rome. Notwithstanding, the contacts between Rome and the Germanic tribes were not completely interrupted. In reality, the cultural and economical influence of the Roman settlements situated to the west of the Rhine, which flourished in the years following the wars, exerted more and more influence on the Germanic tribes to the east of the Rhine. Without a doubt, Romans profited from the import of Germanic products such as meat, grain, leather wares and, probably, also lead (re Germanic lead traders s. Melzer and Pfeffer 2007; Rothenhöfer 2007b; Bode et al. 2007).

Lead artefacts from the Roman military camps east of the river Rhine

Lead artefacts and casting debris from six military camps (Hedemünden, Oberaden, Anreppen, Dorsten-Holsterhausen, Haltern [Westphalia/Hesse (D)] and Dangstetten [Bavaria (D)]), from the Roman civil colony Lahnau-Waldgirmes [Hesse (D)] and from the battlefield of Kalkriese [Lower Saxony (D)], probably the place of the famous Clades Variana (v.s.), were sampled for LIA. Typologically identifiable finds include lead weights, pipe fragments, plumbs and slingshots (e.g., Aßkamp and Rudnick 2007); the majority was, however, amorphous casting scrap.

With c. 150 lead objects, this group is exceptionally large. Consequently, there is a good chance to identify the lead ore deposits used by the Romans as long as they can 


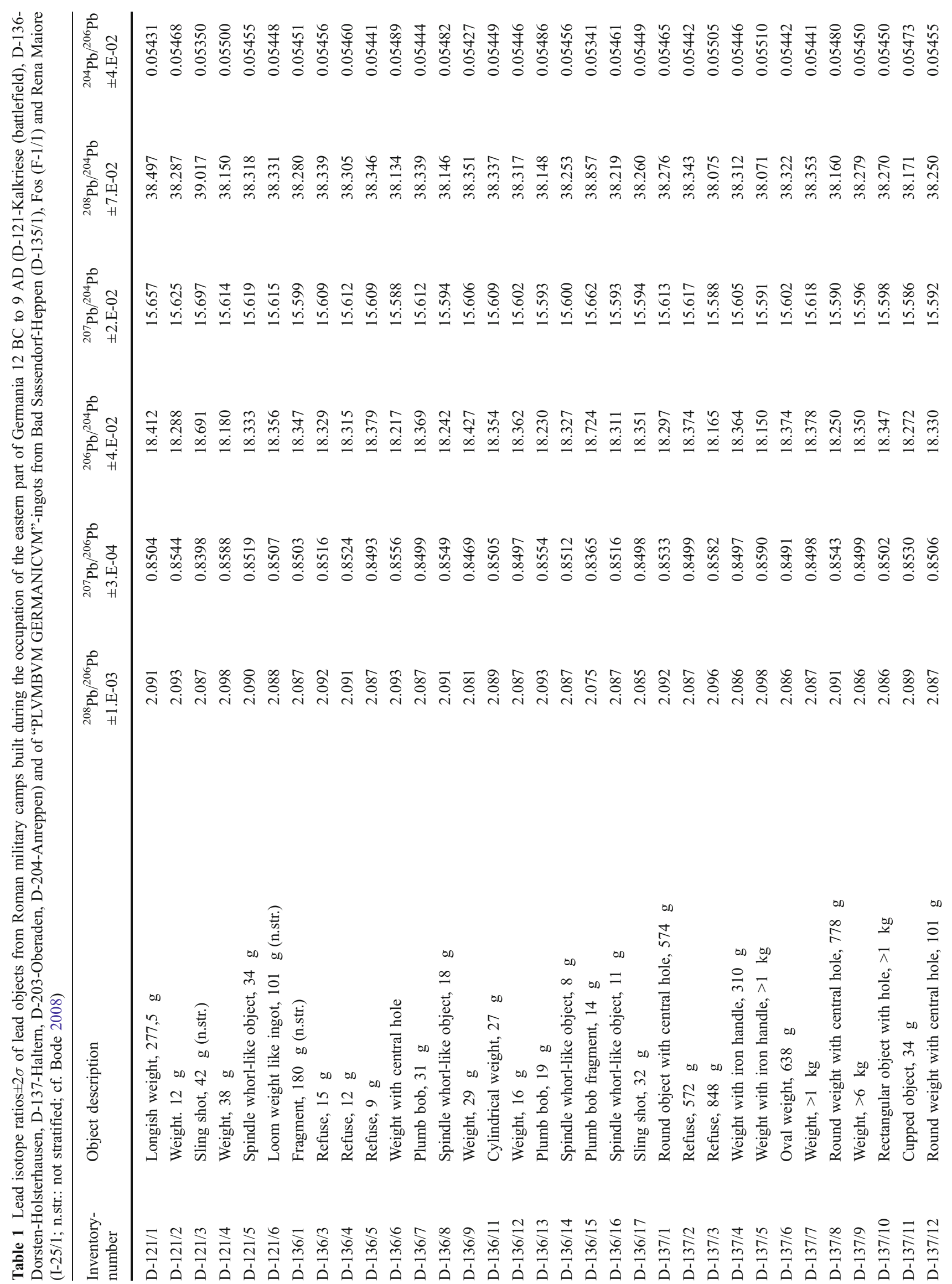




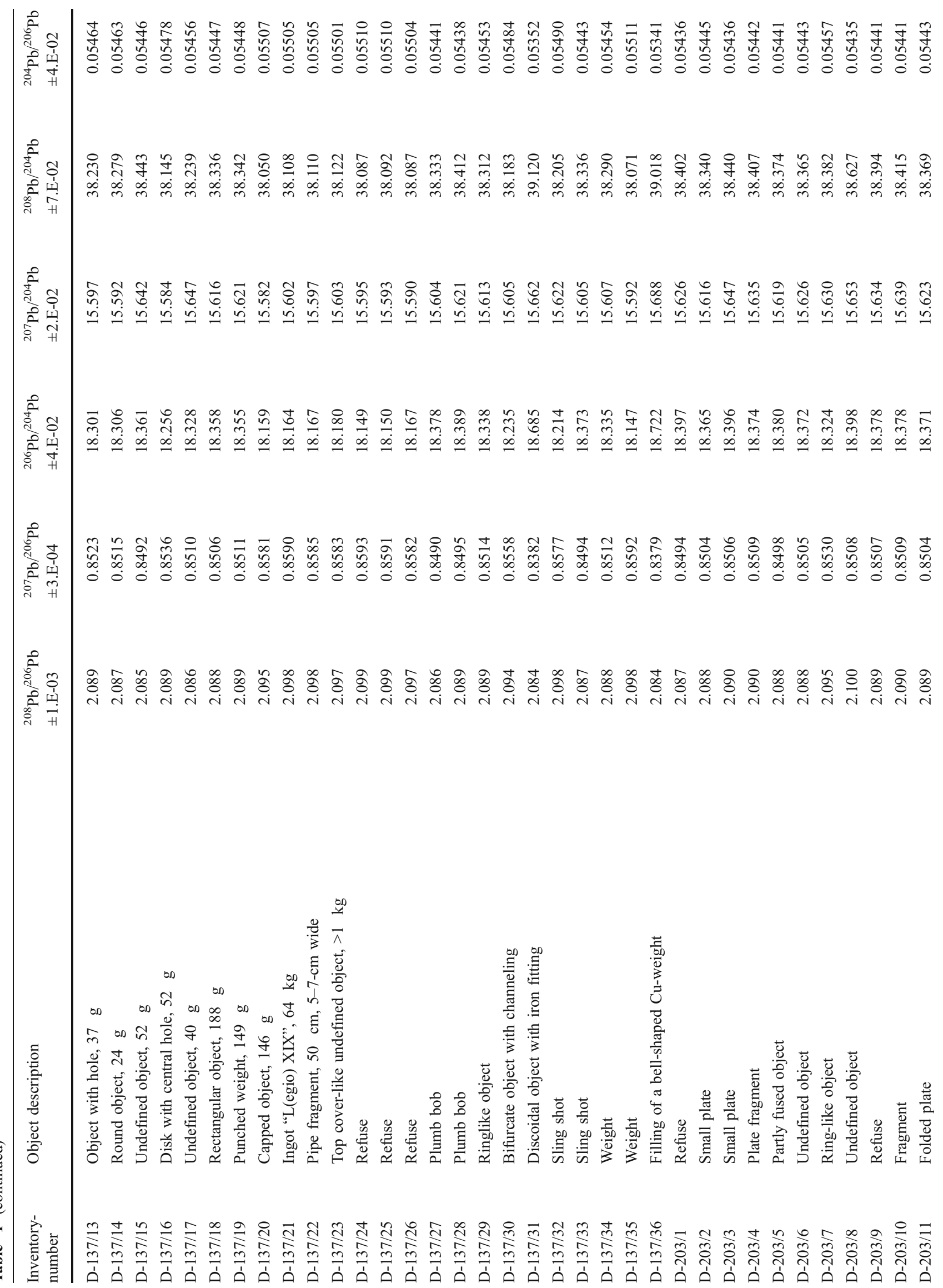




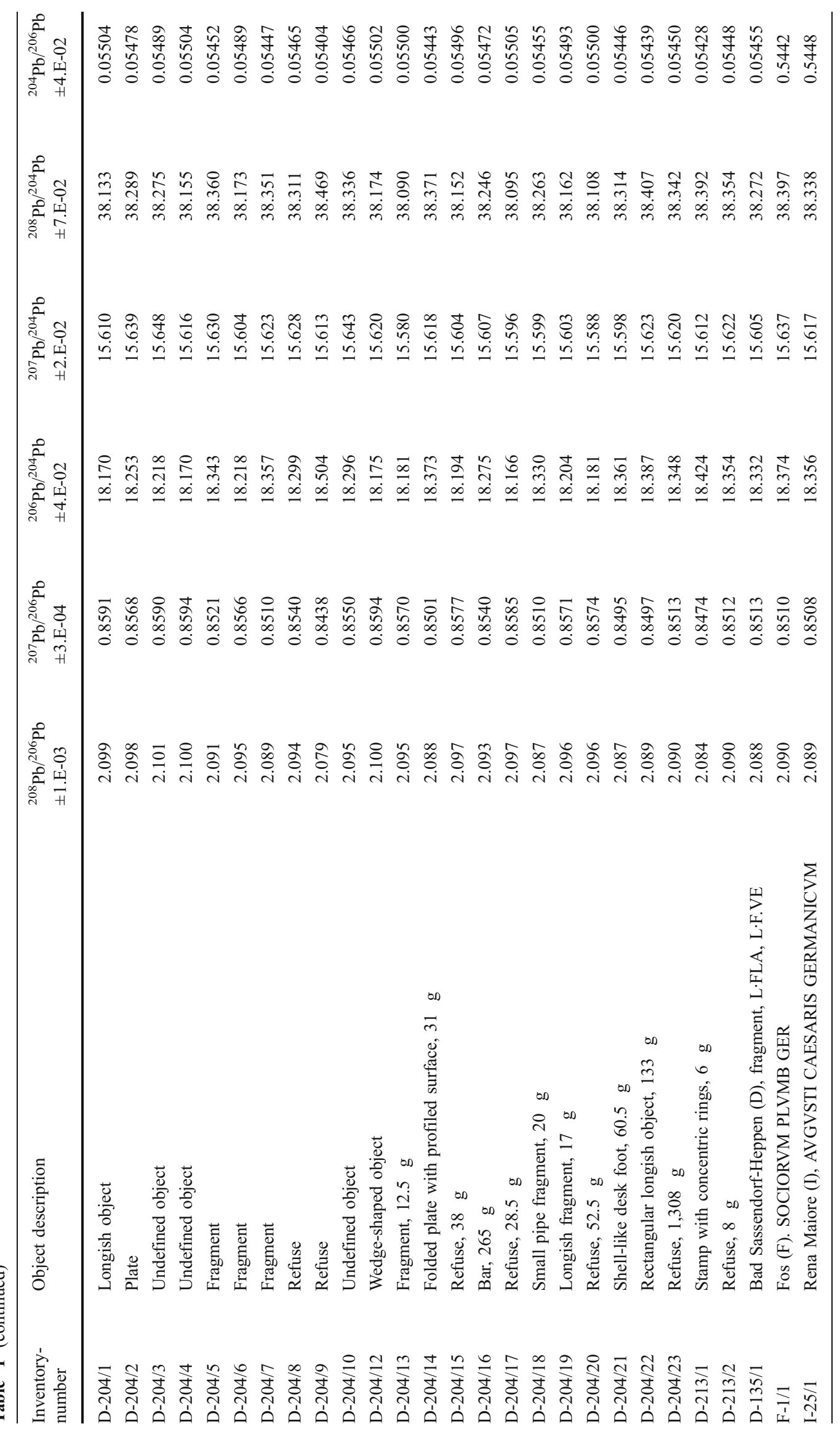


be differentiated by their lead isotope ratios. Furthermore, the data distribution of the lead objects overlapping the lead ore data in the following lead isotope diagrams could also give an indication of the quantity supplied by each of the exploited ore deposits. Since the Roman camps of this study were constructed either during or after the military campaigns from $12 \mathrm{BC}$ to $9 / 8 \mathrm{BC}$, it is quite possible that the verifiably and assumedly exploited ore bodies situated in the subsequently occupied Germanic territory east of the Rhine [i.e., Bensberg district and Brilon district (v.i.)] can be identified using not only archaeological but also scientific methods.

Roman lead ingots and their meaning for the historical sciences

Knowledge about the localization of Roman mines is only partially based on information from literary sources. The ancient textual evidence says little or nothing about mining activities. For example, in Germania, preserved vestiges from the mines rarely lead to a profound understanding of the size, duration and intensity of the metal production in a single mining district. More useful information may derive from metal, in particular, from the massive lead ingots that are found in large numbers in the area of the Roman Empire. Presently, between 2,000 and 3,000 examples are known throughout the Mediterranean and beyond. Many of these ingots have inscriptions which were made during their production and usually reveal information about, e.g., the manager of the mine, provenance or quality of the metal itself.

\section{The "PLVMBVM GERMANICVM"-ingots}

Currently, there are 145 Roman lead ingots known that, according to their inscriptions (and accompanying finds), should have been produced in Augustan-Tiberian Germania (Rothenhöfer 2003; Rothenhöfer 2005; Hanel and Rothenhöfer 2005). Most of them, namely 142 examples, were discovered in two Roman shipwrecks in the Mediterranean (Long and Domergue 1995; Riccardi and Genovesi 2002). Three additional ingots come from Southern France, Belgium (not published yet) and Germany (Schulten 1917; Benoit 1958; LaubenheimerLeenhardt 1973).

In the Rhône delta near Saintes-Maries-de-la-Mer (F), 99 lead ingots (with a total weight of 5.5 tonnes) were recovered from a Roman shipwreck (Long and Domergue 1995). From the cast inscriptions and stamps (L·FL·VERV, $\mathrm{L} \cdot \mathrm{FL} \cdot \mathrm{VE}$ ), it was possible to attribute the ingots to a previously unknown manufacturer with the name Lucius Flavius Verucla (Fig. 1). On eight ingots of this load, the inscriptions not only contain detailed information about the

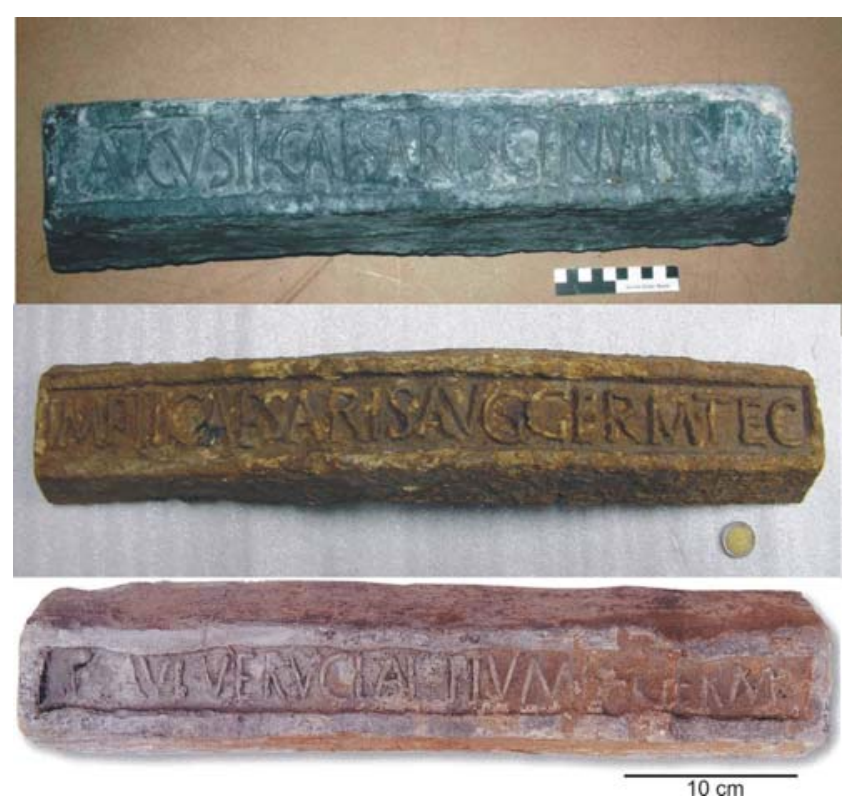

Fig. 1 Three "PLVMBVM GERMANICVM"-ingots from different localities. Above: Example of the 42 AVGVSTI CAESARIS GERMANICVM-ingots from a shipwreck near Rena Maiore (I; Photo A. Hauptmann). Middle: Roman lead ingot from Tongeren (B) with inscription IMP TI CAESARIS AVG GERM TEC (Photo M. Bode, (C) Provinciaal Gallo-Romeins Museum, Tongeren). Below: Example of the 99 Roman lead ingots from a shipwreck near Saintes-Maries-de-la-Mer (F) with inscription FLAVI VERVCLAE PLVMB GERM (Photo Reineke 2008)

name of the manufacturer but also, most probably, about the provenance of the lead: [.] FLAVI VERVCLAE PLVMB(um) GERM(anicum) (Rothenhöfer 2003). Many of these lead ingots were additionally marked with IMP (eratoris) CAES(aris), which means that these ingots were property of the Caesar and can be seen as a tribute from the leaseholder to the owner of the mine (Rothenhöfer 2003). Accordingly, there should have been imperial mining districts within Germania. This hypothesis is supported by the discovery of more "PLVMBVM GERMANICVM"ingots. As part of the cargo from a shipwreck near Rena Maiore (I), 42 lead ingots (with a weight of 2.7 tonnes) with the inscription AVGVSTI CAESARIS GERMANICVM were recovered (Fig. 1). Apparently, these ingots were also produced in Germania and came from an imperial Augustan mine (Hanel and Rothenhöfer 2005). Lucius Flavius Verucla was possibly active during the same period; the surface find of an ingot fragment from his production, which was found at Bad Sassendorf-Heppen (Westphalia) in the temporarily conquered eastern Germania (Schulten 1917), argues for such a concurrent time frame (Rothenhöfer 2003). In total, eight of Veruclas' lead ingots and one of the 42 lead ingots from Rena Maiore were selected for LIA by Trincherini et al. (2001) and Bode (2008; cf. Table 1). 
Aside from the 42 AVGVSTI CAESARIS GERMANICVM-ingots another lead ingot (with a weight of c. $80 \mathrm{~kg}$ ) with a manufacturer's mark was retrieved from the wreck at Rena Maiore (Riccardi and Genovesi 2002). The example was stamped twice with the mark PVDENTIS GERM(anicum), thereby seemingly making known another entrepreneur active in Augustan Germania (Hanel and Rothenhöfer 2005). In 2002, a small lead fragment with a similar marking (Pudens) was found in the historical mining district at Brilon (Brilon district, Sauerland, v.i.) inside a not exactly datable find-spot from the early Roman Imperial period where lead was processed (Hanel and Rothenhöfer 2005). In view of the relative rarity of this name in Germania and its relation to lead, it is possible that the person referred to on both examples is one and the same. The result of LIA carried out on the lead fragment shows that the metal could have been produced from lead ores around Brilon (Bode et al. 2007; Bode 2008); the same could also hold true for the PVDENTIS GERM(anicum)-lead ingot.

A lead ingot from Tongeren (B), the civitas capital of the Tungri, also provides important information (Fig. 1). The inscription IMP TI CAESARIS AVG GERM TEC points to an imperial ownership of a mine and lead production in Germania: since Tiberius is named, a surname of Germanicus can be excluded, and therefore, GERM obviously refers to Germanicum. Lead isotope data of the ingot is not presented in this paper but are plotted together with the other "PLVMBVM GERMANICVM"ingots in Fig. 6.

Another lead ingot weighing $66 \mathrm{~kg}$ was discovered in the Mediterranean at the Rhône delta near Fos (F) (Benoit 1958; Laubenheimer-Leenhardt 1973). Imprinted on its back is SOCIORVM PLVMB(um) GER(manicum). According to the inscription, public contractors had leased a concession for lead production in Germania (Rothenhöfer 2005). The design of the inscription points to an Augustan date or at least to the early Imperial period (pers. comm. Dr. P. Rothenhöfer, Deutsches Archäologisches Institut Munich, Commission of Ancient History and Epigraphy). LIA of this ingot is presented in Table 1 and plotted together with the other "PLVMBVM GERMANICVM"ingots in Fig. 6.

\section{The Roman mines under Augustus and Tiberius in Germania}

The strategic wars led by Rome were, in part, certainly caused by the search for sources of raw materials. Similarly, with the conquest of the Iberian Peninsula, Gaul, Britain, Dalmatia, Dacia, Macedonia, Thrace, Asia Minor and Egypt, the Romans gained access to all of the known ore deposits in the Old World.
The Iberian Peninsula, with the two major ore districts of Cartagena-Mazzarón and the Sierra Morena (Domergue 1987; 1990; Meier 1995), was the most important area for lead production in the Roman Republic. Starting in Augustan times, mines in the Balkans also produced lead but probably in minor quantities (Meier 1995; Genovesi 2006, no lead isotope data available). Lead ore deposits, which soonest could have served the Roman civilization with greater amounts of lead, were located in southern France and Sardinia. But, as in many historical mining regions, younger activities overprinted the old ones so that the exact role of southern France and Sardinia in Roman lead supply cannot be clarified by the archaeological record alone (cf. Davies 1935; Nriagu 1983; de Martino 1985; Begemann and Schmitt-Strecker 1994; Meier 1995; Trincherini et al. 2001).

Previous provenance studies have shown that in Roman Germania, beginning with the military occupation of the Rhineland and probably up to the 4th and 5th centuries, ore deposits in the northern Eifel provided lead at least for regional purposes (Gottschalk and Baumann 2001; Durali-Müller 2005; Rothenhöfer 2007a). The present paper expands those studies to other mining districts in the Sauerland (Brilon district) and in the Bergische Land (Bensberg district), east of the river Rhine in North-Rhine Westphalia (cf. Bode et al. 2007; Bode 2008).

\section{"Mechernicher Bleiberg" (Northern Eifel)}

The most important Roman lead ore district in this area lies between Mechernich-Kommern and Kall-Keldenich, within the so-called Mechernich Triassic Triangle. The impulse to exploit the ore body can most likely be traced back to the construction of the road between Trier (D) and Neuss (D) in the early 2nd century BC. Sherds of Ubian Quinares coins (type Scheer 57 II) from the 2 nd decade BC were found in the mining dumps and shafts near Kall-Keldenich and present a datable period of mining activity (Rothenhöfer 2005). The near-surface mineralization is known as the "Mechernicher Bleiberg" (Fig. 2). It contains silver-poor galena and sphalerite (Schalich et al. 1986). Archaeological finds which prove Roman activities there include extensive tailings of washedout sand and mining trenches as well as troughs, clay and lead lamps, clay piping and wooden gutters (Davies 1935; Petrikovits v. 1958; Schalich et al. 1986; Wegener 1994).

Aachen-Stolberg district (Northern Eifel)

The oldest ceramics and coins from this historical mining district can be found at the "Schlangenberg" southeast from Aachen and date to the 1st quarter of the 1st century AD (Fig. 2). Additionally, some pieces of lead 
Fig. 2 Metallogenic map of the Rhine Massif with its metal ore deposits right and left of the river Rhine (modified after Jochum 2000). The ancient lead ore deposits mentioned in the text (turquoise patterned) are located in the northern part. $\mathrm{The} \mathrm{Pb}-\mathrm{Zn}$-ores of the Brilon district are of epigenetic origin, Bensberg and Aachen-Stolberg districts house hydrothermal $\mathrm{Pb}-\mathrm{Zn}$-veins and the ores of "Mechernicher Bleiberg" mostly are of submarine "exhalative" origin. The Brilon and the Bensberg districts are part of the left side of Germania. Red squares represent early Rhine camps. The military campaigns principally started along the corridors of the rivers Lippe (north of the Ruhr area) and Main (south of the Taunus region (not part of this map)

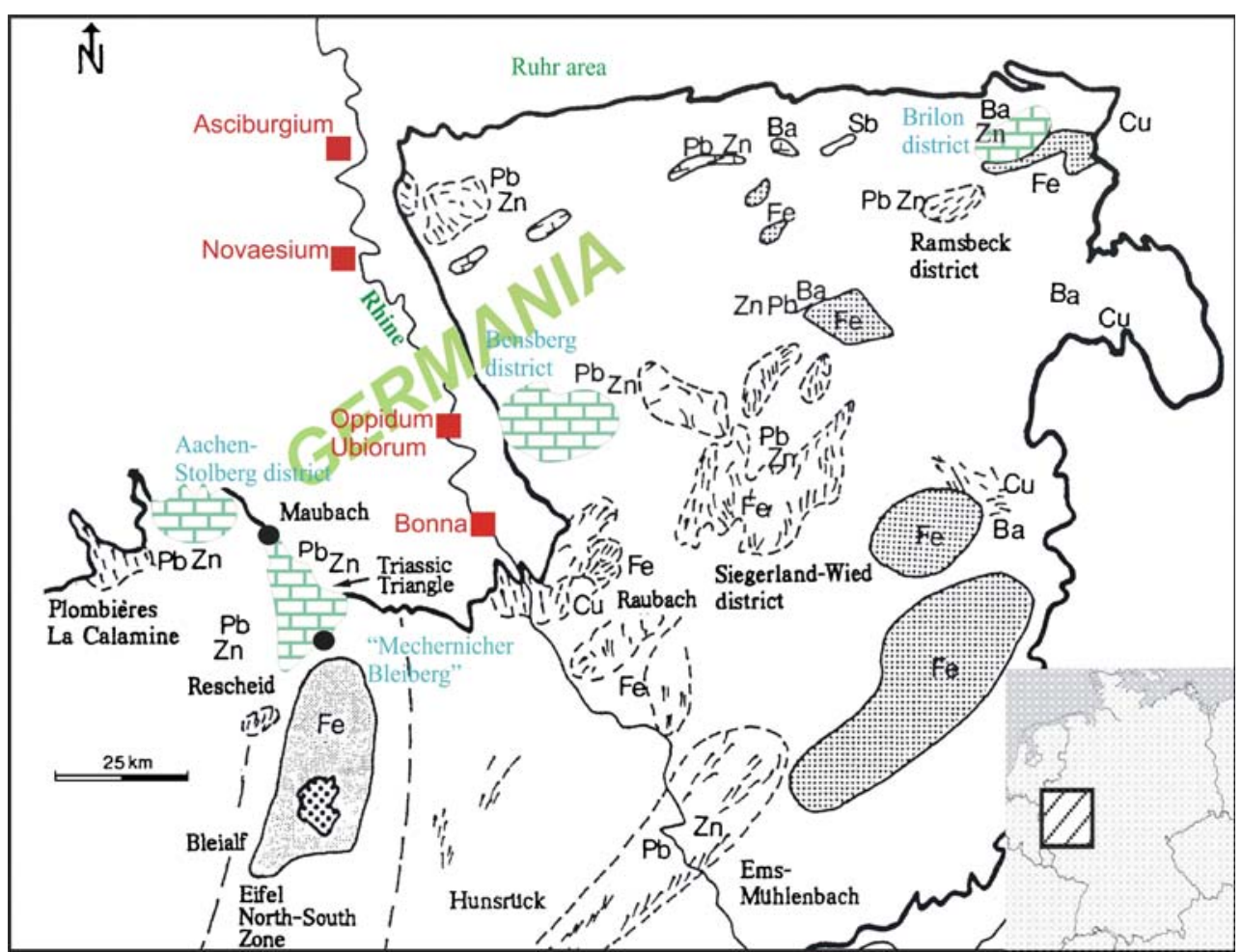

casting, a lead weight and remains of galena were found there that, along with the ceramics and coins, mark the beginning of the mining activities (Löhr and Zedelius 1980). Old pits, collapsed shafts and adits in the vicinity of the "Schlangenberg" are also clear indications of Roman mining (Davies 1935; Löhr and Zedelius 1980; Horn 1987).

\section{Bensberg district (Bergische Land)}

Lead mining was also practised in the Bergische Land, which lies across from Cologne on the opposite bank of the Rhine. In contrast to other parts of Germania east of the Rhine, this area was still under Roman control after the defeat of Varus in 9 AD (Clades Variana, v.s.). Evidence for lead smelting can be found in at least three places in the Bergische Land (cf. Rothenhöfer 2005). The most intensively investigated mine is the "Lüderich" mine of the Bensberg district (Fig. 2) where Roman soldiers produced lead and silver during the first two decades AD (Körlin 2006). Lead isotope data only exist for the "Lüderich" mine (galena, lead objects, slag, litharge; Bielicki and Tischendorf 1991; Zwicker et al. 1991; Bode 2008).

\section{Brilon district (Sauerland)}

In the Brilon mining district, there is only indirect evidence for Roman lead production during the period between 9/8 BC and $9 \mathrm{AD}$ (Fig. 2). Smelting slags that can be found in several places are currently not sufficiently dated and classified and hence, cannot be used to confirm or deny this hypothesis. The research there is still in its initial stages, thus the find of a piece of lead with a Roman name (Pudens) scratched into its surface is especially interesting. The same name was also found on an Augustan lead ingot [PVDENTIS GERM (anicum)] from a shipwreck off the Sardinian coast (Rena Maiore) (v.s.).

Evidence for Germanic lead ore mining, which most likely began in the Brilon district during the course of the 1 st century $A D$, is met with similar difficulties. In spite of numerous lead finds and Germanic lead ingots in native settlements, there are no known smelting sites though LIA have shown that all the lead could have quite possibly come from around Brilon (Bode et al. 2007; Bode 2008). That there is no known native Germanic lead production in pre-Roman times or during Roman occupation reinforces the assumption that the Romans rather than the Germanic tribes initiated lead ore mining in the Sauerland (Rothenhöfer 2007b).

\section{Lead isotope analysis in archaeometry}

For provenance studies of metals, a possibility for comparison, a "fingerprint", is needed that can be clearly traced 


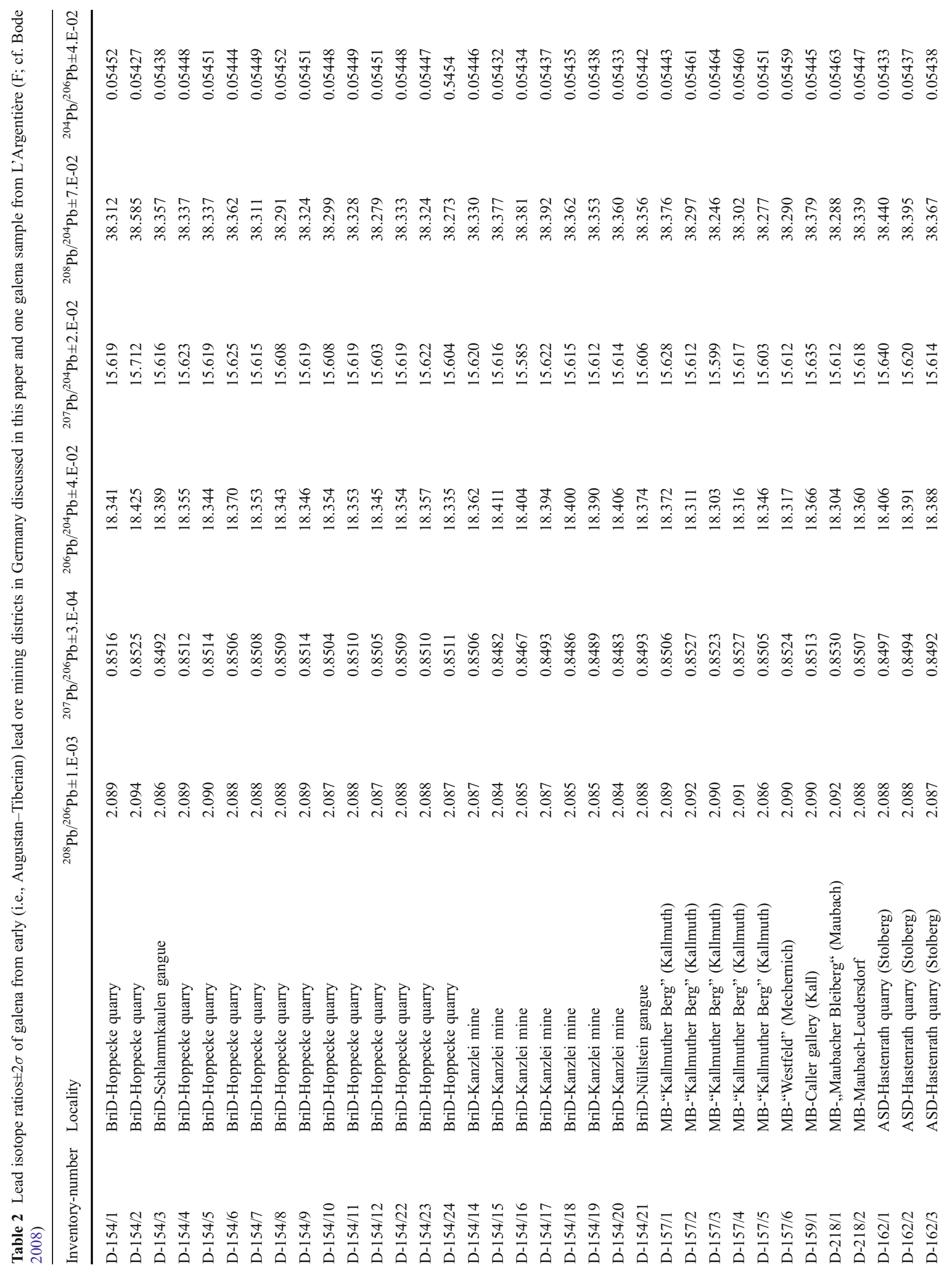




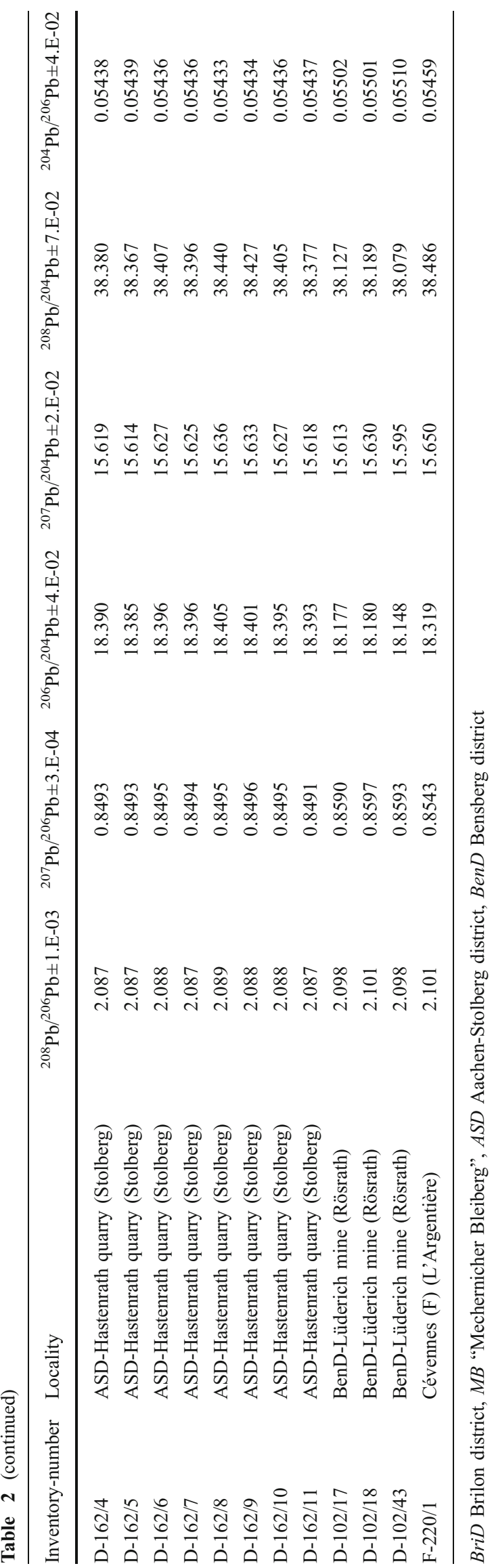

from the ore to the metal. This is mainly done by using the isotope composition of higher-ordered chemical elements, which isotopes have only small relative mass differences. Fractionation, i.e., a shift in the isotope composition from conversion processes such as weathering or smelting is not to be expected in such isotope systems. The element lead, with its four stable isotopes ${ }^{204} \mathrm{~Pb},{ }^{206} \mathrm{~Pb},{ }^{207} \mathrm{~Pb}$ and ${ }^{208} \mathrm{~Pb}$, is especially suitable (cf. Gale and Stos-Gale 2000). Since most of the ores are nearly free of uranium and thorium, the mother isotopes of radiogenic lead $\left({ }^{206} \mathrm{~Pb},{ }^{207} \mathrm{~Pb}\right.$ and $\left.{ }^{208} \mathrm{~Pb}\right)$, the lead isotope composition of the ores is fixed at the time of deposition and depends to first order on the time of ore formation. Especially for lead ores, uranium and thorium contents are insignificant. That is why lead isotopes in ore minerals vary within broader boundaries than is the case for most other chemical elements and their isotopes. Therefore, measurable differences between metal objects or ore bodies are especially expected for lead in contrast to other elements that have very constant isotopic compositions. Additionally, all significant metals that were used in antiquity contain at least a trace of lead whilst it has been proved by direct experiment that lead isotope compositions are not fractionated by such processes as smelting, cupellation, fire refining, etc. (Gale and Stos-Gale 1996).

Notwithstanding, lead isotope analysis is a procedure of exclusion, i.e., a safe assignment of a metal supply area just by LIA is, at last, not attainable. What can be determined with certainty is which ore body does not come into question as a supply area. This is due to the fact that several ore bodies from different localities but of similar age may have indistinguishable lead isotope compositions. Convincing results in provenance investigation of metals are those where LIA and archaeology point to the same mining area.

Generally, a comparison between ore and metal is not only possible for lead itself but also for copper, iron, gold and all materials which contain lead in traces. This is, however, invalid as soon as an object contains recycled scrap metal of different origin. The problem with alloys mixed from two or more components is that all of the individual components can contribute to the lead present in the end product. An exception is very lead-poor tin in ancient bronze (Begemann and Schmitt-Strecker 2008).

The chemical digestion of lead metal and lead ore for lead isotope analysis is comparatively easy. In this study, lead isotope ratios of c. 100 Roman lead objects (including four "PLVMBVM GERMANICVM"-ingots) and c. 50 galena samples were analysed at the Institute of Mineralogy, Westfälische Wilhelms-Universität, with a thermal ionization mass spectrometer [VG Sector 54; cf. Bode 2008, LIA cf. Table 1 (metal) and Table 2 (galena)]. A small amount of each sample $(3 \mathrm{mg})$ was converted into $\mathrm{PbCl}$ using $6 \mathrm{n} \mathrm{HCl}$ (30-ppm solution). One microliter of this solution was then prepared for measurement using 


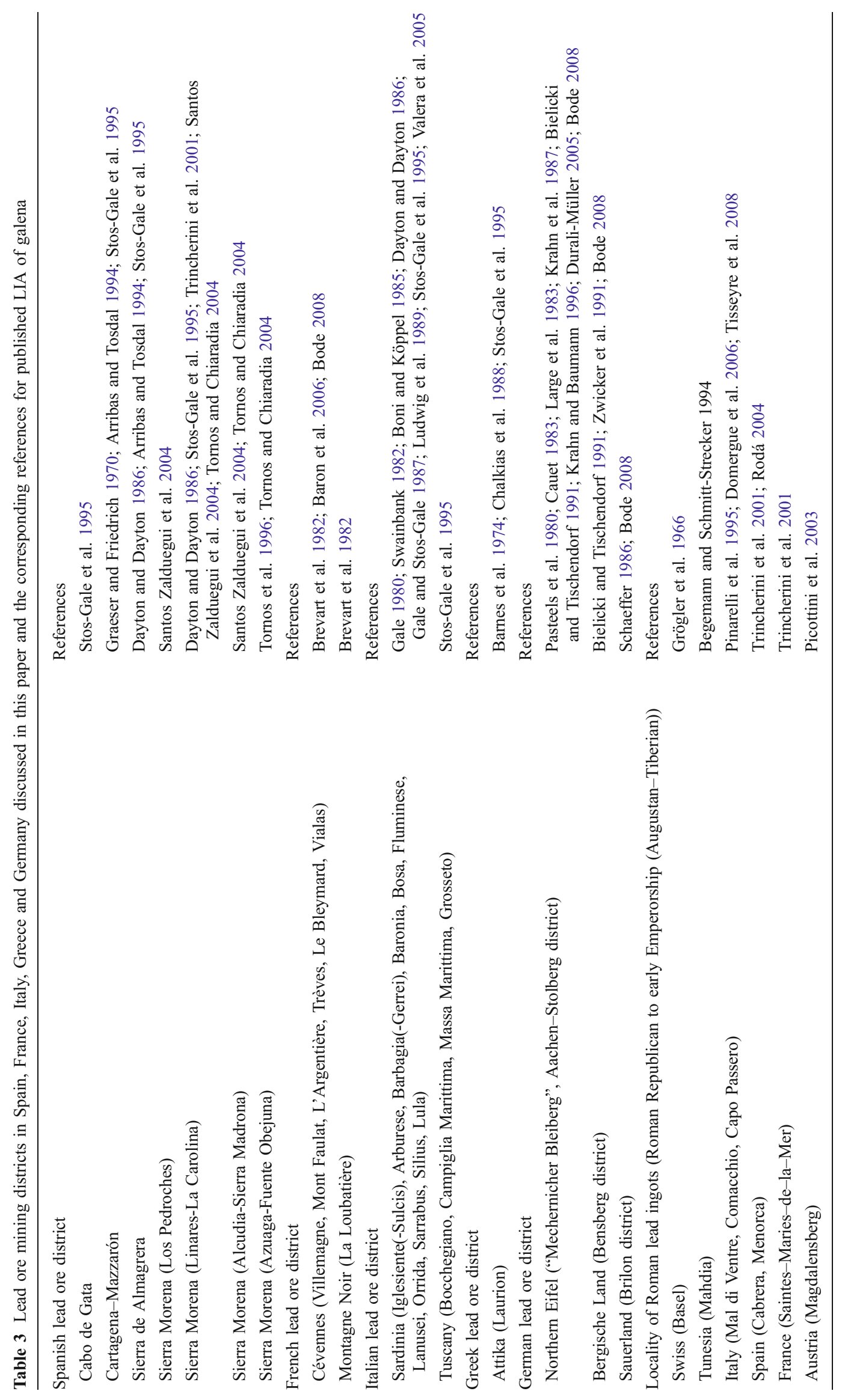


silica gel loading technique (Cameron et al. 1969). External reproducibility (standard deviation) and internal mass fractionation corrections of the isotopes were calculated with the standard NBS 982 (cf. Bode 2008). The other Roman lead objects discussed in this study (c. 50 objects) were measured at the Institute of Mineralogy in Frankfurt, with a multi-collector inductively coupled plasma-mass Spectrometer (Neptune-Finnigan; cf. Durali-Müller 2005). A few milligrammes of lead were dissolved in $2 \mathrm{n} \mathrm{HNO}_{3}$, evaporated and diluted with $2 \% \mathrm{HNO}_{3}(500 \mathrm{ppb}$ lead solution). A $50 \mathrm{ppb} \mathrm{Tl}$ standard was added for monitoring internal fractionation, and the reproducibility was checked using the standard SRM-981.

Following conventions established in archaeometallurgy, the lead isotope compositions of ores and metal artefacts are plotted in binary diagrams using different lead isotopes normalised to ${ }^{206} \mathrm{~Pb}$. When lead isotope ratios of an ore body and of metal objects coincide, then the ore can be considered as a possible source. When this is not the case, then the ore body can be excluded, at least, as the only source, because lead isotope ratios of metals can also lie on mixing or joining lines between two ore bodies. Depending on the position along this line, it is possible to calculate the mixture ratio for lead samples. This does not hold true for other metal objects since copper or iron ores can contain different amounts of lead. When an object contains lead from more than two sources, then the isotope ratio data points will lie within a polygon stretched between the different ore bodies.

\section{Comparison of lead isotope ratios from lead objects of Roman military encampments east of the river Rhine and potential ore bodies in Greece, France, Italy, Spain and Germania}

Next to the mining districts in Germania and the Iberian Peninsula mentioned above, some other Roman mining districts are of particular interest for our provenance study, namely, mineralisations and ore bodies in southern France (Cévennes, Montagne Noir), Italy (Sardinia, Tuscany) and in Greece (Laurion) (references s. Table 3).

Starting with a comparison of the Roman lead objects with lead ore deposits in Greece, France and Italy, it becomes obvious that parts of the artefacts do overlap with lead isotope data of galena from France and Italy in both diagrams (Fig. 3). Greece should be excluded as a possible source for the Roman lead objects. A few finds match with galena from Tuscany in both diagrams. Those galenas could also be part of "mixed" lead objects right of the Tuscany
Fig. 3 Lead isotope ratios of Roman lead objects from Augustan military camps and the battlefield near Kalkriese in the eastern part of Germania plotted in the diagrams $204 \mathrm{~Pb} /$ $206 \mathrm{~Pb}$ vs. $207 \mathrm{~Pb} / 206 \mathrm{~Pb}$ and $207 \mathrm{~Pb} / 206 \mathrm{~Pb}$ vs. $208 \mathrm{~Pb} / 206 \mathrm{~Pb}$. For comparison, LIA of galena from potential lead ore mining districts in Greece, France and Italy are added (references $\mathrm{s}$. Table 3). LIA of the lead objects were made by Durali-Müller (2005) and Bode (2008) (cf. Table 1). 2o-error bars refer to Roman lead objects analysed by Bode (2008)
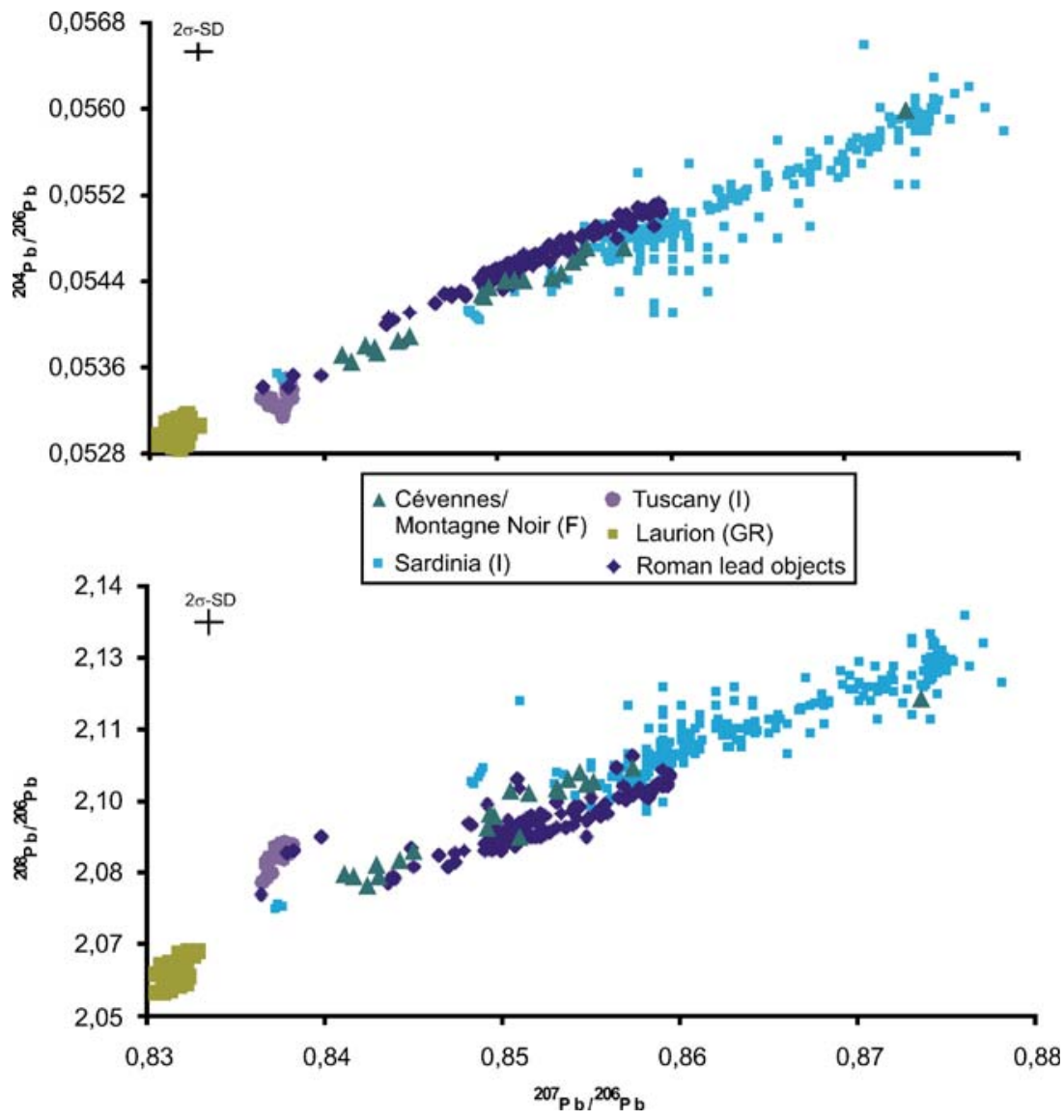
Fig. 4 Lead isotope ratios of Roman lead objects from Augustan military camps and the battlefield near Kalkriese in the eastern part of Germania plotted in the diagrams $204 \mathrm{~Pb} /$ $206 \mathrm{~Pb}$ vs. $207 \mathrm{~Pb} / 206 \mathrm{~Pb}$ and $207 \mathrm{~Pb} / 206 \mathrm{~Pb}$ vs. $208 \mathrm{~Pb} / 206 \mathrm{~Pb}$. For comparison, LIA of galena from potential lead ore mining districts in the southern Iberian Peninsula are added (references s. Table 3). LIA of the lead objects were made by DuraliMüller (2005) and Bode (2008) (cf. Table 1). 2 $\sigma$-error bars refer to Roman lead objects analysed by Bode (2008) (SM: Sierra Morena)

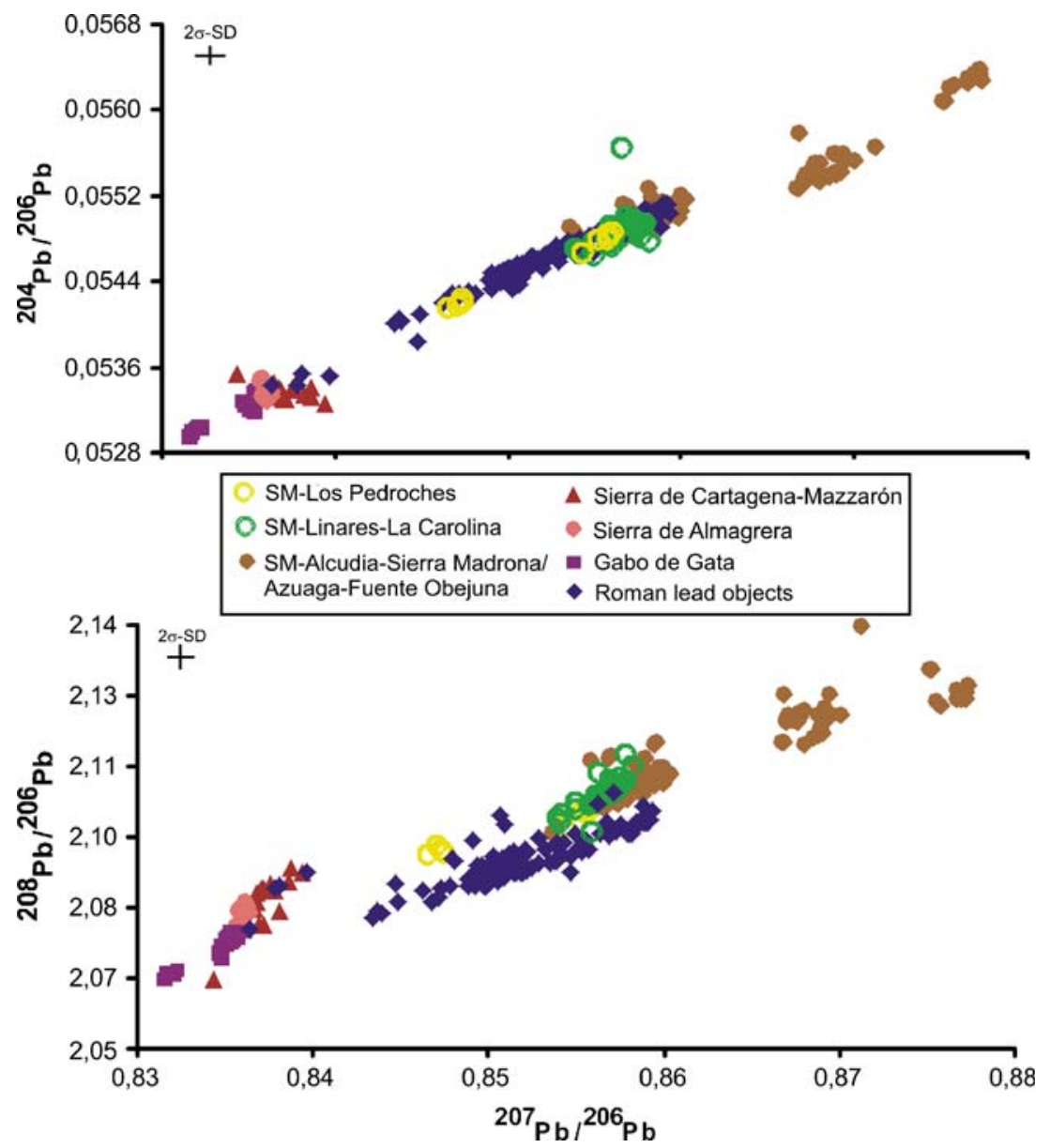

lead ore data field. Although hints for Roman mining activities in Tuscany are missing, it should not be excluded in principle there (pers. comm. Dott.ssa. L. Dallai, Dipartimento di Archeologia e Storia delle Arti, University of Siena). Altogether, lead isotope data of multiple lead objects could be explained by the use of Sardinian, Tuscan or French lead ores, but a convincing correlation with the great clusters of the lead objects in the central part of the diagrams is missing.

In the next step, LIA of the Roman lead objects are plotted against galena data from the important Roman mines in the southern Iberian Peninsula (Fig. 4). In principle, by LIA, all the analysed Roman republican lead ingots from different localities could come either from the Sierra Morena or the Southeast of Spain (e.g., CartagenaMazzarón; for references s. Table 3). Similar to Fig. 3, only a minor amount of Roman lead objects do overlap with the ore data or can be explained by a mixing process. Like Tuscan galena data, galena from Cartagena-Mazzarón convincingly matches with a few objects on the left side of both diagrams. The lead of objects with higher ${ }^{208} \mathrm{~Pb} /{ }^{206} \mathrm{~Pb}$ values than the majority in the middle of the diagrams could come from mining sites at Linares-La Carolina or Los Pedroches in the Sierra Morena or could be composed of lead from ores around Cartagena-Mazzarón and Linares-La Carolina. The large distribution of lead ore data from Alcudia-Sierra Madrona and Azuaga-Fuente Obejuna to the right side of both diagrams is not compatible with the distribution of the lead object data. But obviously, the main part of the objects has a different origin, which could be the early Roman mining sites in Germania.

Although, with no doubt, lead of a certain number of Roman lead objects could, in principle, come from mines in southern France or Italy, we tend to focus on the Spanish lead ore deposits in the following discussion as the second probable lead source next to the German ones. Contrary to France and Italy, in Spain, we have convincing archaeological records for extensive mining and export of lead for the time frame discussed in this paper.

In Fig. 5, Spanish lead ore data is reduced to the best matching lead ore deposits with the objects, namely from Cartagena-Mazzarón in the Southeast of Spain and Los Pedroches and Linares-La Carolina in the Sierra Morena. Here, Roman lead objects from Germania are divided into those from camps of the time of the military campaigns (12 $\mathrm{BC}$ to $9 / 8 \mathrm{BC}$ ) and from camps built after the conquest of the territory right of the river Rhine ( $9 / 8 \mathrm{BC}$ to $9 \mathrm{AD})$. For 
Fig. 5 Lead isotope ratios of Roman lead objects from Augustan military camps and the battlefield near Kalkriese in the eastern part of Germania plotted in the diagrams $204 \mathrm{~Pb} /$ $206 \mathrm{~Pb}$ vs. $207 \mathrm{~Pb} / 206 \mathrm{~Pb}$ and $207 \mathrm{~Pb} / 206 \mathrm{~Pb}$ vs. $208 \mathrm{~Pb} / 206 \mathrm{~Pb}$. Roman lead objects are divided in two groups. One group is built up by objects of camps from the time of the military campaigns (12 $\mathrm{BC}$ to $9 / 8 \mathrm{BC}$ ), the other group by objects of camps after the conquest of the territory right of the river Rhine (9/8 BC to 9 AD). For comparison, LIA of galena from potential lead ore mining districts in the southern Iberian Peninsula and in Germania are added (cf. Table 2, references s. Table 3). LIA of the lead objects were made by Durali-Müller (2005) and Bode (2008) (cf. Table 1). 2o-error bars refer to Roman lead objects and galena analysed by Bode (2008) (SM: Sierra Morena)
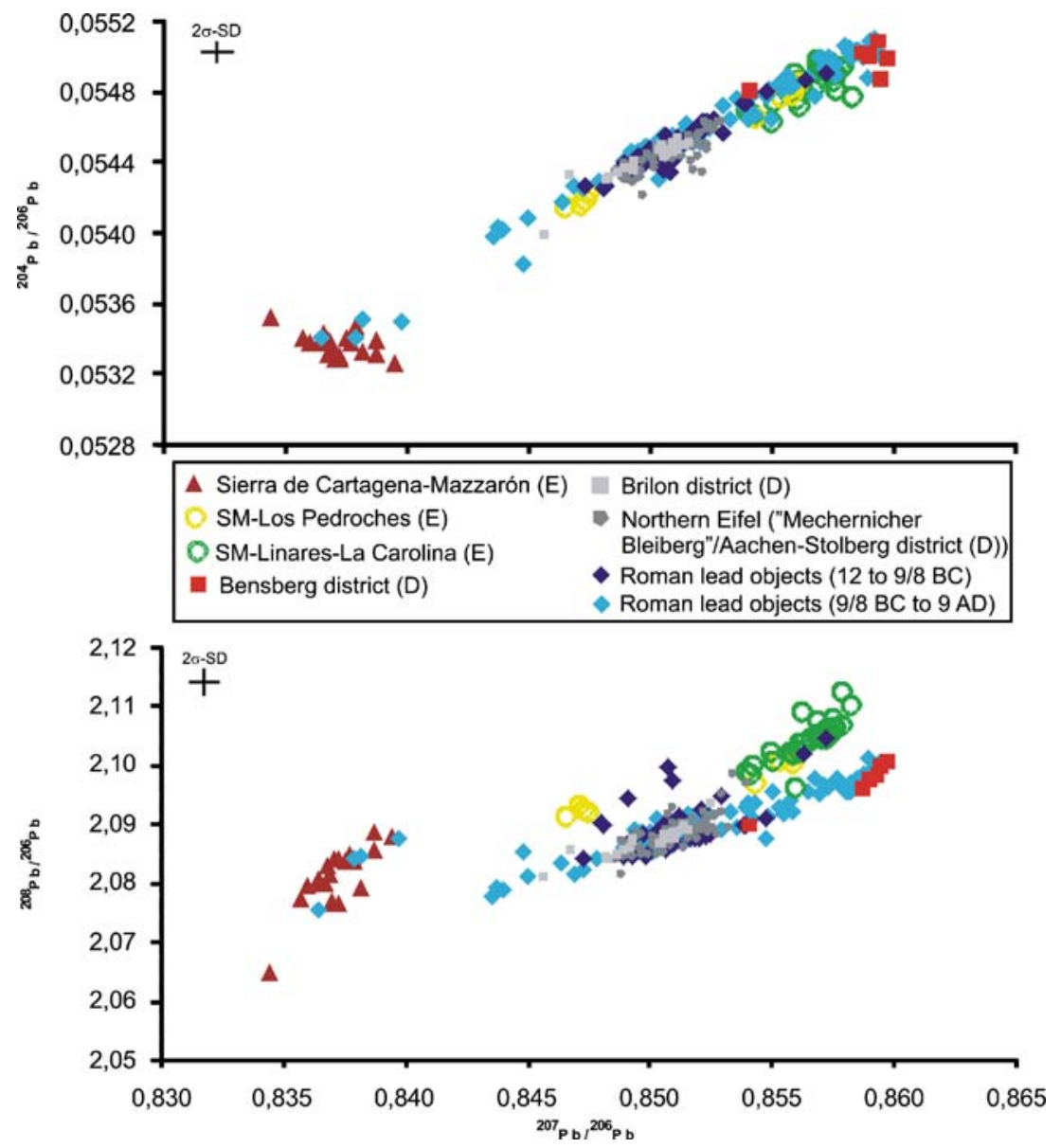

the artefacts of the "early" camps in Germania (dark blue diamonds) only lead ore deposits of the "Mechernicher Bleiberg" in the northern Eifel come into question as German lead source. In fact, the lead of all these objects principally could come from the "Mechernicher Bleiberg" and for a very few from Spain. Those few lead objects show isotope signatures that could have been derived from ores of the Sierra Morena alone (Linares-La Carolina, Los Pedroches) or probably with a fraction of lead from Cartagena-Mazzarón.

For the artefacts of the camps, which were built after the military campaigns (bright blue diamonds), lead could also have been smelted at the mining sites in the newly conquered area right of the river Rhine. In fact, the lead of the objects in the right part of the both diagrams obviously was produced in the Bensberg district in the Bergische Land. Or, for objects with slightly lower ${ }^{207} \mathrm{~Pb} /{ }^{206} \mathrm{~Pb}$ values, lead from there is partly incorporated into the artefacts. Here, more galena analyses would be useful. The Brilon district (Sauerland) where we have indirect hints for Roman lead ore mining in Augustan time, certainly could be a further lead source at this time, but, unfortunately, lead isotope data from galena of both the northern Eifel mining districts and the Brilon district are indistinguishable. The same holds true for the trace element contents (cf. Bode 2008). That four lead objects apparently are of lead from Cartagena-Mazzarón and several objects mixed with this lead (left of the Sauerland/Eifel galena data field) could be an indication that still after the conquest of Germania, Spanish lead was brought to the Rhine camps to assure the lead supply for the legions.

\section{Lead sources of "PLVMBVM GERMANICVM"-ingots}

Figure 6 shows that the lead ingots from the Roman Republican period, the "PLVMBVM GERMANICVM"ingots and the Roman lead ingot from the legio XIX found at Haltern, most probably have the same sources as the Roman lead artefacts from the military camps east of the Rhine. Although some of the Roman Republican ingots on the left side of the diagrams do not overlap with galena data from Cartagena-Mazzarón, all of them could, in principle, come from Southeast Spain. As expected, the lead isotope ratios of the ingots, which normally have been cast directly at the mining sites, do not lie on mixing lines between the Spanish and German lead isotope fields of galena and so, are valid provenance indicators. 
Fig. 6 Lead isotope ratios of Roman Republican lead ingots (references s. Table 3), "PLVMBVM GERMANICVM"ingots (cf. Table 1, references s. Table 3) and the Roman lead ingot from Haltern (D; cf. Table 1, D-137/21) plotted in the diagrams $204 \mathrm{~Pb} / 206 \mathrm{~Pb}$ vs. $207 \mathrm{~Pb} / 206 \mathrm{~Pb}$ and $207 \mathrm{~Pb} / 206 \mathrm{~Pb}$ vs. $208 \mathrm{~Pb} / 206 \mathrm{~Pb}$. For comparison, LIA of galena from potential lead ore mining districts in the southern Iberian Peninsula and in Germania are added (cf. Table 2, references s. Table 3). 2 $\sigma$-error bars refer to Roman lead ingots and galena analysed by Bode (2008). (SM: Sierra Morena)
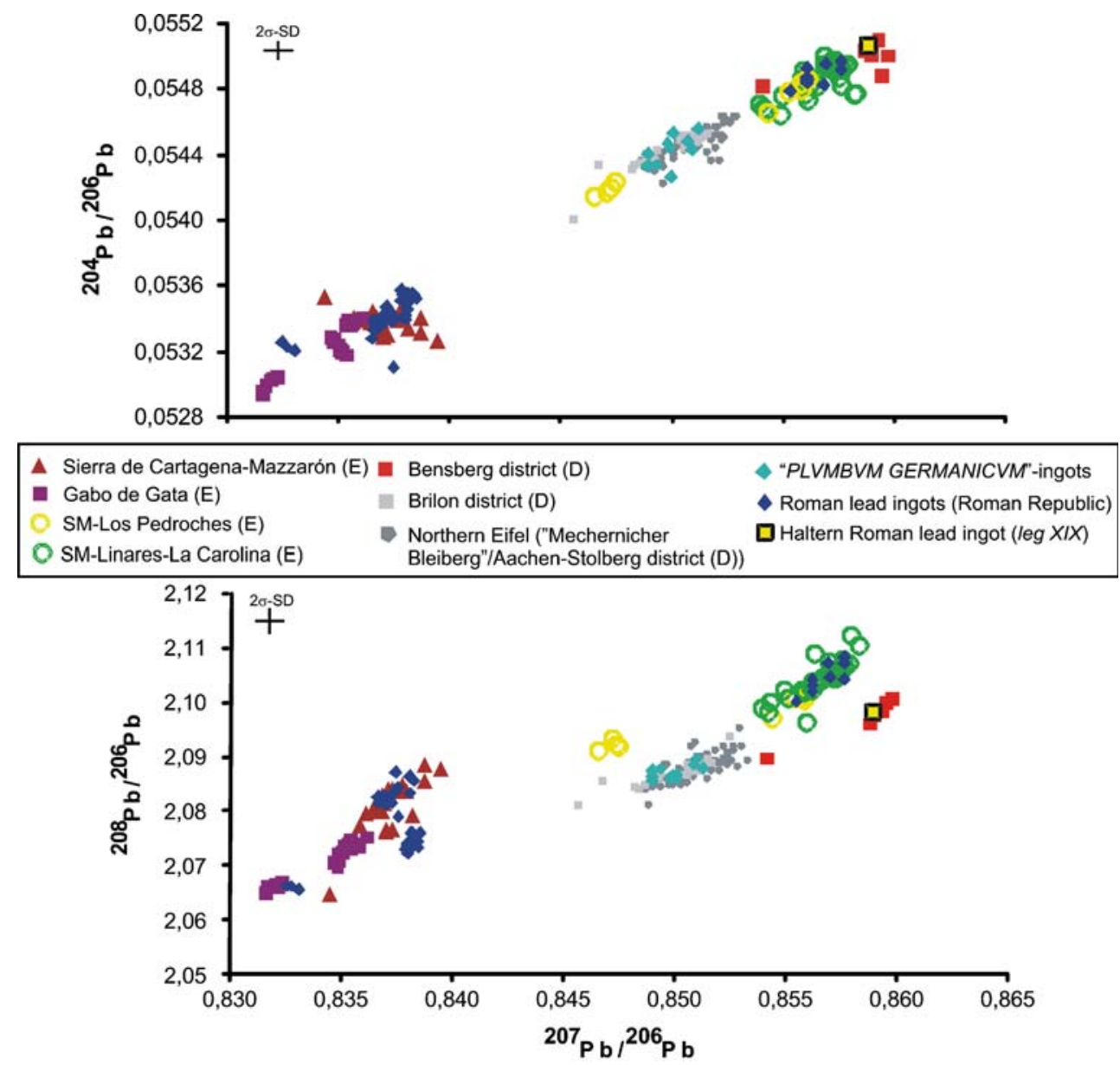

The "PLVMBVM GERMANICVM"-ingots clearly match the Brilon mining district but are also identical with ores from the northern Eifel district. Combined epigraphic investigations carried out on the ingots (Rothenhöfer 2003; Hanel and Rothenhöfer 2005) as well as the evidences for early Roman mining activities in the northern Rhine Massif (v.s.) thus make the source of the lead in Germania very likely. If the Brilon mining district was also a production area for the export of lead is open to discussion, as archaeological evidence is still lacking. Following Figs. 3, 4,5 , and 6 , it is very likely that not only the lead mines of the Iberian Peninsula (and later those in Britain from $43 \mathrm{AD}$ onwards) but also those in Germania played an important role in the supraregional metal supply. The lead produced in Germania was not only used for the military camps and settlements in the Rhineland but also for other cities in the Roman Empire especially Rome itself.

\section{Conclusion}

The distribution of the Roman lead finds in the isotope diagrams shows characteristic clusters exactly where the Augustan-Tiberian lead ore deposits of Germania (Northern
Eifel, Sauerland, Bergische Land) are located. This indicates that the majority of the lead was locally produced, and import of Spanish lead quickly became superfluous. A significant amount of finds from the later camps lie on mixing lines between the different German ore deposits. Note that lead from the single camps did not come from just one German ore deposit (s. Bode 2008). It should be tied to the fact that the lead supply for the Roman troops was centrally distributed, probably from a depot on the Rhine. Since lead ores from the Brilon mining district in the Sauerland cannot be geochemically differentiated from those in the northern Eifel, it is not possible by LIA (and trace element comparison) to determine the role this district played in lead supply after the military campaigns.

Since all analysed "PLVMBVM GERMANICVM"ingots can be dated to the Augustan-Tiberian time (Rothenhöfer 2003; Hanel and Rothenhöfer 2005), it can be assumed, together with the provenance study in this paper, that the lead deposits in Germania most probably were of supraregional importance, at least, for that time span. This is supported by the knowledge that the previously prominent mining districts in southern Spain apparently had slowly begun to lose their economical importance from the 1st century onwards, and the commu- 
nities there had begun to switch over to a more agricultural basis (Wiegels 1977; Orejas and Sánchez-Palencia 2002). Evidence for supraregional export of lead from the Bergische Land is still missing, since, at present, no "PLVMBVM GERMANICVM"-ingots have appropriate characteristic lead isotopic compositions.

Acknowledgements Sincere thanks go to many colleagues who took part in the project. A special thanks to the following historians and archaeologists: Prof. Werner Eck and Dr. Norbert Hanel from the University of Cologne; Prof. Christof Schuler and Dr. Peter Rothenhöfer from the German Archaeological Institute, Munich, Commission of Ancient History and Epigraphy; Dr. Walter Melzer, Dr. Bernd Rudnick and M.A. Ingo Pfeffer from Archaeological Service at Soest; Prof. Thomas Stöllner and Dr. Gabriele Körlin from the German Mining-Museum Bochum; Prof. Wolfgang Ebel-Zepezauer from the Institute of Pre- and Protohistorical Archaeology, Ruhr University Bochum; Prof. Marie-Thérèse Raepsaet-Charlier and Prof. Georges Raepsaet from the Université libre de Bruxelles; Dr. Guido Creemers from the Provinciaal Gallo-Romeins Museum, Tongeren; Dr. Johann-Sebastian Kühlborn and Dr. Rudolf Bergmann from the Westphalian Museum for Archaeology and Dr. Rubens D'Oriano from the Soprintendenza per i Beni Archeologici della Sardegna. Special thanks also go out to the many local historians and archaeologists in Westphalia and Rhineland who supported this project.

\section{References}

Arribas A Jr, Tosdal RM (1994) Isotopic composition of $\mathrm{Pb}$ and $\mathrm{S}$ in base and precious metal deposits of the Betic Cordillera, Spain: origin and relationship to other European deposits. Econ Geol 89:1074-1093

Aßkamp R, Rudnick B (2007) Römische Bleifunde aus Haltern. Soester Beitr Archäol 8:33-40

Barnes IL, Shields WR, Murphy TJ, Brill RH (1974) Isotopic analysis of Laurion lead ores. Archaeol Chem 138:1-10

Baron S, Carigna J, Laurent S, Ploquin A (2006) Medieval lead making on Mont-Lozère Massif (Cévennes, France): tracing ore sources using $\mathrm{Pb}$ isotopes. Appl Geochem 21:241-252

Begemann F, Schmitt-Strecker S (1994) Das Blei von Schiff und Ladung: Seine Isotopie und mögliche Herkunft. In: Hellenkemper-Salies G (ed) Das Wrack Der Antike Schiffsfund von Mahdia. Rheinland-Verlag, Cologne, pp 1073-1076

Begemann F, Schmitt-Strecker S (2008) Bleiisotopie und die Provenienz von Metallen. In: Yalçin Ü (ed) Anatolian Metal IV, Der Anschnitt, Beih 21. Deutsches Bergbau-Museum Bochum, Bochum, pp 125-134

Benoit F (1958) Nouvelles épaves de Provence. Gall 16:5-39

Bielicki K-H, Tischendorf G (1991) Lead isotope and $\mathrm{Pb}-\mathrm{Pb}$ model age determinations of ores from Central Europe and their metallogenetic interpretation. Contrib Miner Petrol 106:440-461

Bode M (2008) Archäometallurgische Untersuchungen zur Blei-/Silbergewinnung im Germanien der frühen Römischen Kaiserzeit. Dissertation, University of Münster, online: http:// nbn-resolving.de/urn:nbn:de:hbz:6-22579580819

Boni M, Köppel V (1985) Ore-lead isotope pattern from the Iglesiente-Sulcis Area (SW Sardinia) and the problem of remobilization of metals. Miner Depos 20:185-193

Bode M, Hauptmann A, Mezger K (2007) Rekonstruktion fruhkaiserzeitlicher Bleiproduktion in Germanien: Synergie von Archäologie und Materialwissenschaften. Soester Beitr Archäol 8:105-124
Brevart O, Dupré B, Allegre CJ (1982) Metallogenic provinces and the remobilization process studied by lead isotopes: lead-zinc ore deposits from the Southern Massif Central, France. Econ Geol 77:564-575

Cameron AE, Smith DH, Walker RL (1969) Mass spectrometry of nanogram size samples of lead. Anal Chem 41:525-526

Cauet S (1983) Géochimie isotopique du Pb et S. Prof Serv Géol Belg 197:1-67

Chalkias G, Vavelidis M, Schmitt-Strecker S, Begemann F (1988) Geologische Interpretation der Blei-Isotopen-Verhältnisse von Erzen der Insel Thasos, der Ägäis und Nordgriechenlands. In: Wagner GA, Weisgerber $G$ (eds) Antike Edel-und Buntmetallgewinnung auf Thasos. Bochum, pp 59-74

Conophagos CE (1980) Le Laurium Antique. Ekdotike Hellados, Athenes

Davies O (1935) Roman mines in Europe. Clarendon, Oxford

Dayton JE, Dayton A (1986) Uses and limitations of lead isotopes in archaeology. In: Olin JS, Blackman MJ (eds) Proceedings of the 24th International Archaeometry Symposium, Washington, 1986 pp 13-41

Domergue C (1987) Catalogue des mines et des fonderies antiques de la Péninsule Ibérique, 2 vol. et une pochette de cartes Sér Archéol VIII. Publications de la Casa de Velázquez, Madrid p. 598

Domergue C (1990) Les mines de la Péninsule Ibérique dans l'antiquité romaine. Collect Éc Fr Rom 127:1-626

Domergue C, Quarati P, Nesta A, Trincherini PR (2006) Retour sur les lingots de plomb de Comacchio (Ferrara, Italie) en passant par l'archéométrie et l'épigraphie. Online: http://arxiv.org/abs/physics/ 0605044. Accessed 5 May 2006

Durali-Müller S (2005) Roman lead and copper mining in Germany. Their origin and development trough time, deduced from lead and copper isotope provenance studies. Dissertation, University of Frankfurt/ Main, online: http://www.mineralogie.uni-frankfurt.de/petrologiegeochemie/forschung/dissertationen/diss0106/index.html

Eck W (2004) Augustus und die Großprovinz Germanien. Köln Jahrb $37: 11-22$

Gale NH (1980) Early Bronze Age lead-silver mining and metallurgy in the Aegean: the ancient workings on Siphnos. In: Craddock PT (ed) Scientific studies in early mining and extractive metallurgy. British Museum, London, pp 63-80

Gale NH, Stos-Gale ZA (1987) Oxide ingots from Sardinia, Crete and Cyprus and the Bronze Age copper trade: new scientific evidence. BARIS 387:159-198

Gale NH, Stos-Gale ZA (1996) Lead isotope methodology: the possible fractionation of lead isotope compositions during metallurgical processes. In: Demirci S, Ozer AM, Summers GD (eds) Archaeometry 94-the Proceedings of 29th International Symposium on Archaeometry, Ankara, 1196 pp 287-299

Gale NH, Stos-Gale ZA (2000) Lead isotope studies applied to provenance studies. In: Ciliberto E, Spoto G (eds) Modern analytical methods in art and archaeology. Wiley, New York, pp 503-584

Genovesi S (2006) L'attività mineraria romana in Moesia in età augustea: alcune considerazioni sui bolli di due lingotti di piombo. Riv stor dell'antich 35:67-97

Gottschalk R, Baumann A (2001) Material provenance of late-Roman lead coffins in the Rhineland, Germany. Eur J Miner 13:197-205

Graeser S, Friedrich G (1970) Zur Frage der Altersstellung und Genese der Blei-Zink-Vorkommen der Sierra de Cartagena in Spanien. Miner Depos 5:365-374

Grögler N, Geiss J, Grünenfelder M, Houtermans FG (1966) Isotopenuntersuchungen zur Bestimmung der Herkunft römischer Bleirohre und Bleibarren. Z Nat 21:1167-1172

Hanel N, Rothenhöfer P (2005) Germanisches Blei für Rom. Zur Rolle des römischen Bergbaus im rechtsrheinischen Germanien im frühen Prinzipat. Ger 83:52-65 
Hopper R (1968) The Laurion Mines: a Reconsideration. Annu Br Sch Athens 63:293-326

Horn HG (1987) Die Römer in Nordrhein-Westfalen. Theiss Verlag $\mathrm{GmbH}$, Stuttgart

Jochum J (2000) Variscan and post-Variscan lead-zinc mineralization, Rhenish Massif, Germany: evidence for sulfide precipitation via thermochemical sulfate reduction. Miner Depos 35:451-464

Körlin G (2006) Römischer Bergbau auf dem Lüderich bei Rösrath, Rheinisch-Bergischer Kreis. In: Köhne R, Reininghaus W, Stöllner Th (eds) Bergbau im Sauerland. Westfälischer Bergbau in der Römerzeit und im frühen Mittelalter. Schriften der Historischen Kommission für Westfalen 20. Verlag des Westfälischen Heimatbundes, Münster, pp 21-31

Krahn L, Baumann A (1996) Lead isotope systematics of epigenetic lead-zinc mineralization in the western part of the Rheinisches Schiefergebirge, Germany. Miner Depos 31:225-237

Krahn L, Baumann A, Friedrich G (1987) Zur Herkunft der Metalle in Vererzungen des Linksrheinischen Schiefergebirges und angrenzender Gebiete: Ergebnisse von Blei-IsotopenAnalysen. Fortschr Miner 65:1-106

Large D, Schaeffer R, Höhndorf A (1983) Lead isotope data from selected galena occurrences in the northern Eifel and north Sauerland, Germany. Miner Depos 18:235-243

Laubenheimer-Leenhardt F (1973) Recherches sur les lingots de cuivre et de plomb d'époque romaine dans les regions de Languedoc-Roussillon et de Provence-Corse. Rev Archéol Narbonn 3:195-197

Löhr H, Zedelius V (1980) Der 'Schlangenberg'. Ein Platz der frührömischen Okkupation bei Stolberg-Breinigerberg, Kreis Aachen. Archäol Rheinl 1979:93-99

Long L, Domergue C (1995) Le veritable plomb de L. Flavius Verucla et autre lingots. MEFRA 107:801-867

Ludwig KR, Vollmer R, Turi B, Simmons KR, Perna G (1989) Isotopic constraints on the genesis of basement ores in southern and central Sardinia. Eur J Miner 1:657-666

de Martino F (1985) Wirtschaftsgeschichte des Alten Rom. Beck, Munich

Meier SW (1995) Blei in der Antike. Bergbau, Verhüttung, Fernhandel. Dissertation, University of Zürich

Melzer W, Pfeffer I (2007) Soest-Ein Zentrum der Bleiverarbeitung im 1. Jahrhundert nach Christus. Soester Beitr Archäol 8:91-104

Nriagu JO (1983) Lead and lead poisoning in antiquity. Wiley, New York

Nriagu JO (1996) A history of global metal pollution. Sci 272:223-224

Orejas A, Sánchez-Palencia FJ (2002) Mines, territorial organization, and social structure in Roman Iberia: Carthago Noua and the peninsular northwest. Am J Archaeol 106:581-599

Pasteels P, Netels V, Dejonghe L, Deutsch S (1980) La composition isotopique du plomb des gisements belges. Implication sur les plan génétiques et économiques. Note préliminaire. Bull Soc Belg Géol 89:123-136

Petrikovits v H (1958) Bergbau und Hüttenwesen in der römischen Rheinzone. Erzmetall 11:594-600

Picottini G, Schroll E, Spindler P (2003) Ein römerzeitlicher Bleibarren vom Magdalensberg. In: Rudolfinum. Jahrb Landesmus Kärnten 2002/2003. Landesmuseum Kärnten, Klagenfurt, pp 153-161

Pinarelli L, Salvi D, Ferrera G (1995) The source of ancient Roman lead, as deduced from lead isotopes: the ingots from the Mal di Ventre wreck (Western Sardinia, Italy). Sci Technol Cult Herit 4:79-86

Reineke B (2008) Plumbum Germanicum. Das Blei der Sauerländer. Handelsbeziehungen vor 2000 Jahren zwischen dem Sauerland und Rom. Briloner Heimatbund-Semper Idem (ed), Brilon, pp 18

Riccardi E, Genovesi S (2002) Un carico di piombo da Rena Maiore (Aglientu). L'Afr Rom 14:1311-1329

Rodá I (2004) Agripa y el comercio del plomo. Rev Mus Arqueol Munic Cartagena 3:183-194
Rosen B, Galili E (2007) Lead use on roman ships and its environmental effects. Int J Naut Archaeol 36:300-307

Rothenhöfer P (2003) Geschäfte in Germanien. Zur Ausbeutung von Erzlagerstätten unter Augustus in Germanien. Z Papyrol Epigr 143:277-286

Rothenhöfer P (2005) Die Wirtschaftsstrukturen im südlichen Niedergermanien. Untersuchungen zur Entwicklung eines Wirtschaftsraumes an der Peripherie des Imperium Romanum. In: Fischer Th (ed) Köln Stud Archäol Röm Prov 7. Marie Leidorf Verlag, Rahden, p 320

Rothenhöfer P (2007a) Verborgen an der Mosel - Ein ungewöhnlicher Metalldepot aus dem 5. Jahrhundert $\mathrm{n}$. Chr. Mit einem naturwissenschaftlichen Beitrag von Michael Bode. Archäol Korresp 37:549-561

Rothenhöfer P (2007b) I am et plumbum excoquere docuimus? - Zum Phänomen der germanischen Bleiproduktion im nördlichen Sauerland während der römischen Kaiserzeit. Soester Beitr Archäol 8:47-55

Santos Zalduegui JF, García de Madinabeitia S, Gil Iingotguchi JI, Palero F (2004) A lead isotope database: the Los PedrochesAlcudia area (Spain); implications for archaeometallurgical connections across southwestern and southeastern Iberia. Archaeom 46:625-634

Schaeffer R (1986) Geochemische Charakteristik und Genese der jungmesozoisch-tertiären Vererzungen im Sauerland (Rheinisches Schiefergebirge). Fortschr Geol Rheinl Westfal 34:337-381

Schalich J, Schneider FK, Stadler G (1986) Die Bleierzlagerstätte Mechernich-Grundlage des Wohlstands, Belastung für den Boden. Fortschr Geol Rheinl Westfal 34:11-91

Schnurbein v S (2003) Augustus in Germania and his new "town" at Waldgirmes east of the Rhine. J Rom Archaeol 16:93-107

Schulten A (1917) Eine neue Römerspur in Westfalen. Bonn Jahrb 124:88-91

Schwinden L (2001) Die Porta Nigra. In: Kuhnen HP (ed) Das römische Trier. Theiss, Stuttgart, pp 143-187

Stos-Gale Z, Gale NH, Houghton J, Speakman R (1995) Lead isotope data from Isotrace Laboratory, Oxford: archaeometry data base 1, ores from the western Mediterranean. Archaeom $37: 407-415$

Swainbank IG (1982) Lead isotopic composition of some galena ores from Sardinia. Period Miner 51:275-286

Tisseyre Ph, Tusa S, Cairns WRL, Bottacin FS, Barbante C, Ciriminna R, Pagliaro M (2008) The lead ingots of Capo Passero: Roman global Mediterranean trade. Oxf J Archaeol 27:315-323

Tornos F, Chiaradia M (2004) Plumbotectonic evolution of the Ossa Morena zone, Iberian Peninsula: tracing the influence of mantlecrust interaction in ore-forming processes. Econ Geol 99:965985

Tornos F, Ribera F, Shepard TJ, Spiro B (1996) The geological and metallogenic setting of stratabound carbonate-hosted $\mathrm{Zn}-\mathrm{Pb}$ mineralizations in the West Asturian Leonese zone, NW Spain. Miner Depos 31:27-40

Trincherini PR, Barbero P, Quarati P, Domergue C, Long L (2001) Where do the lead ingots of the Saintes-Maries-de-la-Mer wreck come from? Archaeology compared with Physics. Archaeom 43:393-406

Valera PG, Valera RG, Rivoldini A (2005) Sardinian ore deposits and metals in the Bronze Age. In: Lo Schiavo F, Giumlia-Mair A, Sanna U, Valera RG (eds) Archaeometallurgy in Sardinia from the origins to the beginning of the Early Iron Age, Monographies Instrumentum 30. Editions Monique Mergoil, Montagnac, pp 4387

Wagner GA, Pernicka E (1988) Blei und Silber im Altertum: ein Beitrag der Archäometrie. Chem Zeit 2:47-56

Wegener W (1994) Archäologische Forschung und Bestandsaufnahme am Mechernicher Bleiberg. Archäol Rheinl 1993:168-170 
Wiegels R (1977) Zum wirtschaftlichen Aufschwung der Baetica zur Zeit Trajans und Hadrians. In: Wiegels R (ed) Studien zur Römerzeit in Gallien, Germanien und Hispanien. Konkordia, Bühl/Baden, pp 119-126

Wiegels R (2007) "Immensum bellum"-ein "gewaltiger Krieg". In: Wiegels R (ed) Die Varusschlacht-Wendepunkt der Geschichte? Theiss, Stuttgart, pp 117-127
Zwicker U, Gale NH, Stos-Gale Z (1991) Metallographische, analytische und technologische Untersuchungen sowie Messungen der Bleiisotope an Otto-Adelheid-Pfennigen und Vergleichsmünzen meist aus dem 9.-11. Jahrhundert. In: Hatz G, Hatz V, Zwicker U, Gale NH, Gale Z (eds) Otto-Adelheid-Pfennige. Commentationes de Nummis Saeculorum IX-XI., Nova Ser. 7, Almqvist-Wiksell International, Stockholm, pp 59-146 